\title{
Importance of Science Education to National Development and Problems Militating Against Its Development
}

\author{
Aina Jacob Kola* \\ Physics Department. College of Education (Tech.), Lafiagi, Kwara State, Nigeria \\ *Corresponding author: akoja64@hotmail.com
}

Received April 05, 2013; Revised June 11, 2013; Accepted July 22, 2013

\begin{abstract}
This paper focused on the review of science education in Nigeria, its importance to national development and problems militating against its development. The paper viewed insecurity and corruption as major problems of science education development in Nigeria. As way forward the paper suggested life imprisonment for any corrupt individuals; government should invest on agriculture to provide job for people and scholarship for science students among others.
\end{abstract}

Keywords: science education, national development, insecurity, corruption

Cite This Article: Aina Jacob Kola, "Importance of Science Education to National Development and Problems Militating Against Its Development.” American Journal of Educational Research 1, no. 7 (2013): 225229. doi: 10.12691/education-1-7-2.

\section{Introduction}

Science education deals with sharing of science content and process with individuals who are not considered traditionally to be member of the scientific community; the individuals could be students, farmers, market women or a whole community. Science education in Nigeria concentrates on the teaching of science concepts, method of teaching and addressing misconceptions held by learners regarding science concepts.

Science education is very important to the development of any nation [21] that is why every nation must take it very serious in all institutions of learning. Many of the developed worlds were able to achieve so much in science and technology because of science education. Launching of sputnik by the Russian government in October, 41957 would not have been possible if not for the position they placed physics in science education [21].

Science education comprises three subjects namely biology, chemistry and physics which are combined with education and over the year there has been low enrolment of these courses in our institutions as identified by [2]; causes of this low enrolment include society disdain, mockery of teacher and low prestige of teachers [19].

Interestingly, as important as these courses are, students' performance has not been encouraging in them and this is worrisome and called for investigation [13]. The table below shows students 'enrolment and performance in WAEC in the three subjects that make up science education from 2005-2009.

Table 1. Enrolment and performance of student in biology, chemistry and physics in WAEC from 2005-2009

\begin{tabular}{|c|c|c|c|c|c|c|}
\hline Year & biology & & chemistry & & physics & \\
\hline & Total entry & $\begin{array}{c}\text { \%pass at grade } \\
\mathrm{A}_{1}-\mathrm{C}_{6} \\
\end{array}$ & Total entry & $\begin{array}{c}\text { \%pass at grade } \\
\mathrm{A}_{1}-\mathrm{C}_{6} \\
\end{array}$ & Total entry & $\begin{array}{c}\text { \%pass at grade } \\
\mathrm{A}_{1}-\mathrm{C}_{6}\end{array}$ \\
\hline 2005 & $1,051,557$ & 35.74 & 349,936 & 50.94 & 344,411 & 41.50 \\
\hline 2006 & 1,082556 & 35.61 & 352,452 & 50.95 & 345,225 & 43.84 \\
\hline 2007 & 1,072602 & 33.57 & 432,230 & 45.96 & 427,398 & 58.05 \\
\hline 2008 & $1,285,048$ & 33.94 & 428,513 & 44.44 & 424,893 & 48.26 \\
\hline 2009 & 1,903552 & 33.87 & 442,091 & 45.97 & 429,174 & 43.56 \\
\hline
\end{tabular}

Source: WAEC Office Yaba, Lagos Nigeria.

Despite all the great things science education can accomplished in the national development of a nation there are many problems militating against it especially in
Nigeria. This paper focused on the importance of science education and problems militating against the development of it and the way forward. 


\section{Importance of Science Education to National Development}

Science education is very important to the development of any nation in many areas. A graduate of physics education can be self employed as opined by [22]. Many of the physics graduates have some knowledge of electronics that is enough for them to be able to have a little period of training as apprentices and then stand alone as electronic technician. For instant, Semiconductor is very important in the modern technology that if properly learnt it is enough for one to stand upon for a living; semiconductor physics is part of what any graduate in physics will learn and should learn. In [1] semiconductor, is very important in a growing economy like ours in Nigeria; it is useful in ceramic industry and a well trained physics education graduate can be well established in ceramic industry.

Without science education Information and Communication Technology would be impossible. Science and technology will not be possible without science education; for instance engineering, medicine, architecture etc will not be possible if there is no one to teach the students the core subjects needed for these courses.

Biology education is very important to any growing economy like Nigeria. Many graduates of biology education are self employed and employers of labour; many owned schools for themselves where people works and earn their living while some are in to fish business.

There are colleges of education where students of chemistry department are taught how to make dye and chalk; graduates of these departments can establish their own chalk business as soon as they graduate. If supported with fund many schools do not need to buy chalk outside anymore and they can equally produce for other schools.

\section{Problem of Science Education Development}

\subsection{Security}

Security issue in Nigeria has been worrisome for more than two years now because of insurgence of Niger Delta and Boko Haram as averred by Horsfall [10]. Stretching the averment further, the former is politically motivated while the latter is religiously motivated; the reason for the insurgence is trivial to this paper but the effects on science education development is very germane.

People in Nigeria lives in fear of uncertainty of death from bomb explosion: of gunshot from terrorist or armed robber and many a time from kidnappers. The lives of nationals living in Nigeria are in perpetual danger of abduction or kidnapping. Lecturers and students don't know their fate every day until they retired to bed at night; even while sleeping they cannot sleep and close their two eyes because of armed robbers.

The recent attacked on a northern university where students and lecturers were cold bloodedly murdered including a professor of chemistry still remains an insomnia in academic arena. Science infrastructures built with huge amount of money for schools had been destroyed while gas and oil installations vandalised; the resultant effects of these is on education.

Many parents have lost their job and the effect is on the children; these children could not complete their education and eventually drop out of schools. According to [11], these dropouts are used by politician as thugs, for assassinations and robbers robbing banks, poison the societies and make everybody feel unsafe. Majority of these dropout students are very brilliant who could have become renowned science educators the country would be proud of.

Schools were closed down in many parts of the country; universities, polytechnics, colleges of education, secondary and primary schools where learning environment are no longer safe for learning remain in long compulsory holiday for months. [2] posited that anywhere students were not able to attend schools regularly for fear of bomb explosion or kidnapping will not be able to interact socially and this will affect their learning. Many brilliant students who should have been an asset for the academic institutions had been killed by terrorist while many had suffered untold hardship in the hands of kidnapper which later affected them both emotionally and academically.

[5] posited that Nigerian higher institutions have become a place of worry to everybody because of the activities of cultists. A cultist who graduated in school through examination malpractices in many time end up in classroom as a teacher since teacher is the easiest job anyone could get in Nigeria because of lack of professionalism. The question that should come to mind is that, what can such teacher teach when he / she got the certificate by fraudulent means? These are many of the teachers we have in most of our schools; they got there through their godfathers who are politicians.

Examination malpractices are the other of the day in the country institutions of learning as observed by [8], even in teachers training institutions. Many of these students harassed teachers and intimidate them and any teacher who failed to yield to their demand risk losing his/ her life or any of the family. A teacher who is not secure while doing his / her job cannot put in the best. Cultists are all over the institutions of learning posing serious danger to academic communities. Worsen enough is science teachers also being cultist and encouraging all forms of examination fraud thereby discouraging hard work among serious science students.

\subsection{Corruption}

Corruption has eating deep into Nigeria system and it is manifesting in every sectors including education. In Nigeria today it is not what you know but whom you know, that is why [14] said recruitment to job is tied down to criteria such as political favouritism, geographical area or quota system. Many of the teacher training institutions and universities cannot boast of the best academic staff because the best probably do not have godfather who can help them. Appointment is no longer based on merit but on whom you know and the amount you can offer for such job. Admission into higher institutions of learning is not on merit but on whom you know also.

Purchases of science equipment to schools are no longer done transparently since it is either the chief 
executive of the school or any of his or her relation who do the supply. In this case they neither supply the required specification nor the required quantity; in most cases they don't even supply anything. Most of the science laboratories are empty building or buildings filled with fake or obsolete science equipment which are useful for nothing but mere demonstration.

Money meant for staff training are diverted to personal account while selections of those who benefit in staff training is on whom you know syndrome. All these bounced back on the quality of science education the nation produces.

Nigerian leaders are corrupt that is why we lack stable political system of government which affect science education as posited by [20] that in any stable political system, teachers and their education system are well catered for. Science teachers are not well catered for in Nigeria instead they are looked upon by the politicians as beggar.

Corruption is the greatest challenge to development of science education in Nigeria; corruption leads to many problems the country is facing presently. According to [17] corruption leads to slow movement of files in offices, extortion in highways, ghost workers in work places, election irregularities and many more. Corruption makes school administrator mismanaged fund meant for purchasing science equipment and asked science teacher to make sure student still pass in examinations by all means. In many universities and research institutes, research has become history because government preferred to use research money for election or hire security for the family of government officials than science education research.

Nigeria is a multiethnic country; this is affecting the country in many ways especially in education. The world is in era of science and technology; every nation is craving for development in Information and Communication Technology [ICT] which cannot be fully achieved without science education. Parents encourages their children to study science oriented courses which is good; children who have no ability for such courses opted for courses in humanity and art. When the time of employment come those who opted for humanity and art courses would be given job related to sciences without prerequisite qualification. Those who originally studied sciences are schemed out of the job because of ethnicity; the attitude discourages young ones from studying science education.

Employment is no longer based on merit; those who are qualified for teaching science are not given employment because they don't have 'godfather' in the government. Teaching appointment is done based on nepotism and favouritism. This is affecting the development of science education in the nation.

There is corruption in the land and no one is spared neither is any organ of government spared [2]. Lecturers in higher institutions have turned colleges and universities to supermarket shops where they sell handouts and books at outrageous prices. Staffers of many polytechnics have taken over the affair of the institution because the chief executives are corrupt in awarding contract that never existed and mismanaged fund meant for science equipment. They sell books and handouts at a 'cutthroat' price without being checked. Male lecturers molest female students who are not willing to dance to their music of promiscuous life style. All these discouraged students who want to study science education and killed the morale of those who are studying the course already.

Scholarships and bursary meant for science students are diverted to non science students because of ethnicity. Where the scholarship is given to science students they introduce unnecessary bureaucracy into it that students may not get the money for many years or give up of the scholarship.

\subsection{Political}

Nigeria has not been having a stable political system of government since her independence in 1960. Stable political system of government is very essential to educational development of any nation [19]. Military ruled for 34 years in Nigeria out of 53 years of existence as a sovereign nation; these years can be regarded as an era of colossus waste in both human and natural resources for Nigerians. These leaders have no regard for education but concentrate on establishing their government for long years. The few years of civilian rule has been years of lack of focus; government educational program changed according to the taste of the political party in power. Many science equipment and infrastructures are lying in waste in our schools because of instability in political government.

Yearly budget of Nigeria government revealed lack of focus and insincerity to good and quality education. [6] observed that Nigeria government has not met the UNESCO recommendations of $26 \%$ of the total budgetary allocation to education sector as reflected in her yearly budget. This budget has not been favourable to education; quoting from [6], the allocation to education in 2003 was7\%; 2004 was $12 \%$ while 2005 was $11 \%$, this figure did not show government commitment to education.

\subsection{Economy}

Nigeria is blessed with many natural resources on which her economy rest upon; however over dependent on petroleum has seriously affected the economy. The effect is on science education since science equipment and apparatus are inadequate in the country and the cost of importing these materials is high because of exchange rate. According to [7], all effort to shift focus of economy from oil industry to other economic activities has not yield positive result because of corruption.

Science teacher's salary and other allowances are not paid. science equipment are not supplied due to declining in output and slow economic growth because of labour distortions, redundancy of the workforce, brain drain among others [15].

\subsection{Teacher}

Science teachers are key factor to be considered when talking about the development of science education in any nation. There are shortages of qualified science teachers in Nigerian schools. So called science teachers are not professionally qualified. They may have the knowledge of the subject but lack the method. [4] on his study of challenges and prospects of primary science teaching affirmed that there are unqualified science teachers in our schools. Attitude of many teachers to teaching are discouraging; they have been teaching for many years 
without upgrading their certificate by going for in-service training. This affects their output and it is a problem to the development of science education.

Science teachers should use different strategies as there is no single universal approach for specific class. Many science teachers still hold to chalk and talk method which is not appropriate for science teaching in this age [3] Lack of good strategies in the teaching of science is affecting student performance and at long run affects student enrolment [16]. The table below shows students' enrolment in some years back in science in a college of education. Students don't want to offer science in school because teachers are not making its teaching interesting; thereby affecting students' enrolment in schools as seen in table below.

Table 2. Students' enrolment in science

\begin{tabular}{|c|c|c|c|}
\hline & 1996 & 1997 & 1998 \\
\hline & & & \\
\hline Biology & 14 & 12 & 09 \\
\hline Chemistry & 02 & 06 & 10 \\
\hline Physics & 01 & 04 & 02 \\
\hline
\end{tabular}

Source: Olawuyi, 2011

\subsection{Way Forward}

There is no problem without solution, therefore what is happening presently in Nigeria as it affects the development of science education have solution if Nigerians are ready to pay the price. Nigerians must be ready to wage total war against corruption; it should be a war that everybody must take part in. There should be laws made specifically for corruption and this law must be enforced no matter whom the corrupt person may be. The law should touch every aspects of life; it should not be limited to money alone as it is presently.

Any government official who favoured anybody in admission, employment and promotion based on ethnicity or religion should be seriously sanctioned as someone who stole government money.

Various professional bodies in tertiary institutions should rise up to the present challenge and ensure they curtail the excesses of their members in schools. There should be no sales of handout in universities, polytechnics and colleges of education. Violation of this law should be dismissal from the service and any book to be sold should be properly screen to know its worth in content and money.

Nigerians should change their orientation; worshipping wealth and position is not the best for us because it encourages corruption. Someone who went to jail for stealing public money should not come out and become hero or king he should be seen as a bad person who has lost his respect and dignity.

Finally on corruption, the ongoing constitution review must be taking serious and it should stipulate a life imprisonment for any corrupt person; might it be in government establishment or private establishment, corruption is corruption once it is established the individual should be sent to life imprisonment.

Government should provide employment for young graduates; Nigeria is blessed with abundant resources that if properly harness unemployment will reduce drastically in the nation. Government should invent on agriculture since the nation is blessed with fertile lands. If government can invent on agriculture, there will be job for the jobless and there will be improvement in economic security of the nation.

Scholarship should be awarded to science students and be thoroughly monitored to ensure money is release on time for same purpose.

\section{Conclusion}

In the light of the above review it is obvious that science education is very important to national development; insecurity and corruption are the major problems militating against its development in Nigeria. However, there are other problems like unstable political system of government, poor economy, poor method of teaching and teachers' attitude to teaching.

Overcoming the problems is the responsibility of everybody in the country. To overcome the problems government must create more job; corruption must be shun everywhere in the country; there must be continuity of government good program; diversification of economy to agriculture is necessary and science teachers must be ready for change in their method of teaching and attitude to work.

\section{References}

[1] Aina, J.K. The Economic importance of conductor, semiconductor and insulator. Retrieved from http://www.amazines.com/article_detail.cfm?articleid=4246828.

[2] Aina, J.K. Security challenges in Nigeria; Causes and effects on science education. Retrieved from

http://www.basearticles.com/Art/932483/39.

[3] Aina, J.K. Teaching aids improvisation in the teaching and learning of physics in secondary schools Retrieved from http://www.articlesbase.com/science-articles/teaching-aidsimprovisation-in-the-teaching-and-learning-of-physics-insecondary-schools-5675240.html.

[4] Aina, J.K. Challenges and prospects of primary science teaching in Nigeria. Continental J. Education Research, 5(2), 32-37.

[5] Ajuwon, B.Y \& Oyeniyi, F.A. Tackling the menace of cultism and indecent dressing: Implication for educational reform and consolidation, South-West Journal of Teacher Education. 3, 318330 .

[6] Akindutire, I.O. Teacher education in democratic Nigeria: challenges and the way forward. South- West Journal of Teacher Education, 3, 107-128.

[7] Babatunde M. A \& Adefabi, R. A. Long run relationship between education Economic growth in Nigeria: Evidence from the Johansen's cointegration Approach. Paper presented at the Regional Conference on Education in West Africa: Constraints and Opportunities, Senegal.

[8] Bello, G. Analysis of examination malpractices perpetrated by pre-service teachers:A case study of Kwara State College of Education, Ilorin, Nigeria. Journal of Professional Teachers, 1 (2), 21-35.

[9] Filani, J. B. The efficacy of functional education in democratic sustenance and its Implication for vocational counselling, SouthWest Journal of Teacher Education 3, 231-243.

[10] Horsfall, A. K Comprehensive and sustainable peace and Security in plural society: Challenges to Nigeria internal security. A speech Delivered at two-day- peace and security summit in Abuja.

[11] Ihindian, D.M. Society ills of early school dropouts as they affect social Development. Journal of women in Colleges of Education, 7, 107-111.

[12] Ikotun, A.O. Adult education as a weapon for self fulfilment in a democratized Nigeria. South- West Journal of Teacher Education, 3, 209-218.

[13] Kola, A. J. Uses of Instructional Materials for Teaching and Learning Physics in Edu and Patigi Local Government Areas, Nigeria, International Journal of Research in Education, 4(1\&2), 74-79. 
[14] Mfon, E.E. Educational reforms and the agenda of technical and vocational educationFacilities in Nigeria. International Journal of Research in Education, 4(1\&2), 280-285.

[15] Ndiyo, N. A. Adynamic analysis of education and economic growth in Nigeria. The Journal of Development Areas, 41(1), 1-16.

[16] Oladejo, M.A, Olosunde,G.R, Ojebisi,A.O \& Isola,O.M. (2011). Instructional materials and students' academic achievement in physics: some policy implications. European Journal of Humanities and Social Sciences, 2(1), ISSN 2220-9425.

[17] Olagunju, O. Corruption control in Nigeria: Holistic approach. Advance in Arts, Social Sciences and Education Research. 2 (1), 76-84.

[18] Olawuyi, J.A. A survey of male and female enrolment and academic Performance in science. Nigeria Journal of Gender and Development 2(1), 186-192.
[19] Okebukola, P.A.O. Curriculum implementation in Nigeria. Strategies For the $21^{\text {st }}$ century. Journal of the Institute of Education, Lagos state University, 1, 1-6.

[20] Oloyede, E.O. Science education and technological development in Nigeria. International Journal of Research. in Education, 4 (1\&2), 95-103.

[21] Omosewo, E.O. Views of physics teachers on the need to train and retrain Physics teachers in Nigeria. African Research Review, 3 (1), 314-325.

[22] Tunde, O, Akintoye, O.H. \& Adeyemo, S.A. Career prospects inPhysics education in a quest towards entrepreneurial skill Development. Research Journal of Social Sciences. 1 (6), 1-5.

[23] WAEC. Senior Secondary Certificate Examinations. Chief Examiners’ Report, Lagos Office, Nigeria. 